\title{
CARDIAC, HEMODYNAMIC AND RENAL FUNCTIONS IN CONGESTIVE HEART FAILURE DURING INDUCED PERIPHERAL VASODILA- TATION; RELATIONSHIP TO STARLING'S LAW OF THE HEART IN MAN $* \dagger$
}

\author{
By BRUCE J. SOBOL, RICHARD H. KESSLER, BERTHA RADER AND \\ LUDWIG W. EICHNA
}

\author{
(From the Department of Medicine, New York University College of Medicine and the Third \\ [New York University] Medical Division, Bellevue Hospital, \\ New York, N. Y.)
}

(Submitted for publication June 30, 1958; accepted September 11, 1958)

The present study of the hemodynamic effects of induced peripheral vasodilatation had two purposes: one, to determine what changes are produced in cardiac, hemodynamic and renal functions of man in congestive heart failure when vascular pressures are lowered by noncardiac means, and two, to determine whether Starling's law of the heart applies in intact man, especially in congestive heart failure.

Expanding on the observations of Frank (1) on the frog heart, Starling, with Patterson and Piper $(2,3)$, determined in the isolated heartlung preparation of the dog that cardiac output increased progressively as ventricular filling pressure (2) and ventricular diastolic volume (3) increased (ascending limb of curve); however, beyond a point considered to indicate a failing myocardium, cardiac output decreased with further increments in ventricular filling pressure or diastolic volume (descending limb of curve). The final generalization derived from these observed relationships Starling (4) then expressed as the law of the heart: "The energy of contraction, however measured, is a function of the length of the muscle fiber." Starling's law has been extrapolated to the intact, humorally and neurogenically homeostatic animal, including man, and has come to dominate present concepts of both normal and abnormal cardiac function. Such extrapolation requires validation.

The applicability of Starling's law to the more intact animal has been investigated by Sarnoff

\footnotetext{
* Presented in part at the Sixty-Ninth Annual Meeting of the Association of American Physicians, Atlantic City, N. J., May 1, 1956.

$\dagger$ This work has been supported by grants-in-aid from the Life Insurance Medical Research Fund and the New York Heart Association, Inc.
}

and his collaborators, Berglund, Isaacs, Case and Sarnoff (5-8), in the anaesthetized, open-chested dog with the heart in situ and its nerve supply intact but its circulation completely isolated and subjected to measurement. In large measure, the relationships between cardiac work and ventricular filling pressure were similar to the results obtained by Starling. Two modifications evolved: one, ventricular function did not follow a single stroke work-filling pressure curve but rather a series or family of similar curves, each curve determined by the circulatory state at the time (anemia, aortic constriction, coronary artery constriction, induced epinephrinemia); two, a descending limb on the ventricular work-filling pressure curve did not occur in the "normal" satisfactory preparation but appeared when the myocardium was "compromised," as by severe anemia, severe coronary artery constriction or shock. Several features of these experiments, especially the large changes in blood volume required to alter the filling pressures and the relatively short periods during which the altered pressure-flow relationships were determined, still raise the question whether the observed results are applicable to man with normal, and especially failing, circulations in a steady state for long periods.

Several studies suggest that Starling's law may apply in man. McMichael, with Sharpey-Schafer and Howarth $(9,10)$, and Judson, Hollander, Hatcher, Halperin and Friedman (11), observed an increase in cardiac output (hence cardiac work since arterial pressure did not change) when the elevated intracardiac pressures of subjects in congestive heart failure were lowered by phlebotomy or by inducing venous stasis in the limbs. These observations have the disadvantage that phle- 
botomy reduces blood volume and the cuffs inducing venous stasis can be maintained for periods which may be too short to permit attainment of circulatory equilibrium.

The advent of vasodilator drugs suggested the possibility of lowering ventricular filling pressure by noncardiac means for sufficiently long periods to attain circulatory equilibrium at a lowered pressure level and, thereby, to permit testing of the applicability of Starling's law to man. The present experiments were designed to lower ventricular filling pressure by producing primary peripheral vasodilatation, then observing whether cardiac function altered as predicted by the law of the heart: an increase in cardiac work when the elevated ventricular filling pressure in congestive heart failure was lowered, and a decrease in cardiac work when normal filling pressure was reduced.

\section{PROCEDURES, METHODS AND SUBJECTS}

Gencral. The plan of study was to measure all functions simultaneously during a control state, during induced and maintained vasodilatation and again on return of the control state. The drug Arfonad ${ }^{\circledR}$, a thiophanium derivative [d-3,4(1',3'-dibenzyl-2'-ketoimidazolido)-1,2-trimethylene thiophanium d-camphor sulfonate], was chosen to produce vasodilatation and lower vascular pressures because this drug has no known direct myocardial or cardiac action. Its effects are produced by blocking sympathetic and parasympathetic ganglia and perhaps also by direct peripheral vascular dilatation (12, 13).

Cardiac output was determined by the direct Fick (14) method. Intracardiac and systemic vascular pressures were obtained directly and recorded with strain gages and electronic recorder. Renal hemodynamic functions were measured by clearance techniques (15) and electrolyte concentrations by flame photometer. Standard methods were used to determine the following: oxygen and carbon dioxide in blood (16), room air (17) and exhaled air (17) ; the concentrations of inulin (18), para-aminohippurate (19) and sodium and potassium (flame photometer) in blood and urine; the plasma and blood volumes (20). Determinations were made in successive periods of 15 to 20 minutes duration, with cardiovascular dynamic measurements made at the midpoint of the periods and renal hemodynamic functions and water and electrolyte excretions measured over the entire period. The nature, timing and sequence of the necessary procedures have been described previously in detail $(21,22)$. Renal hemodynamics and urinary excretions were determined in only one-half of the experiments.

Procedures. The observations were made in the morning on supine subjects without breakfast. A control elec- trocardiogram was taken and the urinary bladder was catheterized. The intravenous infusion of inulin and para-aminohippurate was delivered continuously at $1 \mathrm{ml}$. per minute by a Bowman pump. A double lumen intracardiac catheter was placed with the distal opening in the pulmonary artery and the proximal opening in the right ventricle. A systemic artery was cannulated. A slow intravenous infusion of 5 per cent dextrose in water was begun and the system was provided with a three-way stopcock to permit switching from dextrose infusion to Arfonad ${ }^{\circledR}$ infusion without the subject's knowledge.

After three periods of control measurements the intravenous infusion of Arfonad®, $1 \mathrm{mg}$. per $\mathrm{ml}$. in 5 per cent dextrose in water, was begun and delivered continuously by an infusion pump. The Arfonad@ infusion was started at $0.5 \mathrm{mg}$. per minute and adjusted at 5 to 10 minute intervals until the desired degree of vasodilatation, as determined by the level of arterial pressure, was obtained. This level was maintained for one hour, during which three periods of determinations were made, with their midpoints 15, 30 and 60 minutes after attaining the desired level of vasodilatation. The infusion of Arfonad was then discontinued and after the vascular pressures had returned to control levels, or as close as it appeared they would return, the final period of determinations was made. While awaiting return of the control state, blood volume was determined by the Evans blue dye ( $\mathrm{T}-1824)$ method (20).

When possible, pulmonary "capillary" or "wedge" pressure was obtained during the third control, the third vasodilatation and the one postvasodilatation periods. Right atrial pressure was recorded during vasodilatation only on those occasions when the catheter could not be placed in the pulmonary artery. Right atrial pressure was routinely recorded during removal of the catheter at the close of the observations. Arterial hematocrits were obtained during the control period and again during the postvasodilatation period. Blood oxygen capacity was determined twice, once on samples pooled from the control periods and the second time on samples pooled from the later vasodilatation periods. The corresponding values were used to calculate arterial oxygen saturation for the individual periods.

Even though Arfonad ${ }^{8}$ was infused in small doses, ventricular filling pressure could not be lowered without a concomitant reduction in systemic arterial pressure. Therefore, the dose of the drug was carefully regulated and the fall in systemic arterial pressure was always controlled. In hypertensive patients arterial pressure was lowered to normal, or slightly higher, levels; in normotensive subjects systolic arterial pressure was lowered to 100 to $110 \mathrm{~mm}$. $\mathrm{Hg}$. These pressures served as criteria for the desired degree of vasodilatation and were maintained for one hour. Circulatory collapse and severe hypotension were specifically avoided.

Calculations. Standard calculations were used, at times modified as required by substitutions and assumptions which led to the actual formulations used. Surface 
area was always based on edema-free weight. When measured right atrial pressure was not available, its value was taken to be the corresponding right ventricular end diastolic pressure minus the difference observed between right ventricular end diastolic pressure and right atrial pressure measured when the catheter was removed at the end of the observations. In occasional instances an available right atrial pressure was substituted for an unavailable right ventricular diastolic pressure. In calculations requiring pulmonary "wedge" pressure (pulmonary vascular resistance and left ventricular minute and stroke work) the following substitutions were made in those periods where this measurement was not available: The single value obtained during vasodilatation was used in calculations for both the maximum vasodilatation period and the average of the vasodilatation periods; values obtained during the control period or the postvasodilatation period were substituted for each other when one of the measurements was not available.

The formulae used were: systemic vascular resistance $=\left(\mathrm{SA}_{\mathrm{m}}-\mathrm{RA}_{\mathrm{m}}\right) \div$ C.O. ; pulmonary vascular resistance $=\left(\mathrm{PA}_{\mathrm{m}}-\mathrm{PC}_{\mathrm{m}}\right) \div$ C.O. ; renal vascular resistance $=\left(\mathrm{SA}_{\mathrm{m}}\right.$ $\left.-R_{m}\right) \div R B F$. Vascular resistances are expressed as $\mathrm{mm}$. $\mathrm{Hg}$ per $\mathrm{L}$. per minute, since nothing is gained by the more elaborate calculation into fundamental units.

Left ventricular minute work index $=\left(\mathrm{SA}_{\mathrm{m}}-\mathrm{PC}_{\mathrm{m}}\right) \times$ C.I. $\times 14.4 \div 1,000$; right ventricular minute work index $=\left(\mathrm{PA}_{\mathrm{m}}-\mathrm{RV}_{\mathrm{d}}\right) \times$ C.I. $\times 14.4 \div 1,000 ;$ stroke work index $=$ minute work index of corresponding ventricle $\times 1,000 \div$ V.R. Minute work index is expressed as $\mathrm{Kg}$. $M$. per $\mathrm{M}^{2}$ per minute and stroke work index as $\mathrm{Gm}$. M. per $\mathrm{M}^{2}$ per beat.

The symbols are defined as follows: $\mathrm{SA}_{\mathrm{m}}=$ mean systemic arterial pressure, mm. $\mathrm{Hg} ; \mathrm{RA}_{\mathrm{m}}=$ mean right atrial pressure, $\mathrm{mm}$. $\mathrm{Hg} ; \mathrm{PA}_{\mathrm{m}}=$ mean pulmonary arterial pressure, $\mathrm{mm} . \mathrm{Hg}$; $\mathrm{PC}_{\mathrm{m}}=$ mean pulmonary "wedge" pressure, $\mathrm{mm} . \mathrm{Hg} ; \mathrm{RV}_{\mathrm{d}}=$ right ventricular end diastolic pressure, $\mathrm{mm}$. $\mathrm{Hg}$.

C.O. = cardiac output, L. per minute; C.I. = cardiac index, L. per $M .^{2}$ per minute; $R B F=$ renal blood flow in $\mathrm{L}$. per minute $=$ renal plasma flow $\div(1-\mathrm{Hct})$, where Hct $=$ hematocrit, expressed as a decimal ; V. R. = ventricular rate, per minute.

\section{RESULTS}

Subjects. Table I presents clinical information regarding the 17 patients on whom 21 experiments were performed. The subjects have been divided into four groups: Group I, congestive heart failure-five normotensive and five hypertensive cardiac patients with typical clincial congestive heart failure indicated by low cardiac indices and high A-V oxygen differences; Group II, partial cardiac compensation-two normotensive and two hypertensive cardiac patients clinically recovered from congestive heart failure by appropriate therapy and without signs or symptoms of heart failure but with below normal cardiac indices and $\mathrm{A}-\mathrm{V}$ oxygen differences above 6 volumes per cent; Group III, noncardiac and cardiac compensation - two noncardiac subjects convalescing from pneumonia and alcoholism, respectively, and three cardiac patients, one normotensive and two hypertensive, fully compensated from congestive heart failure, receiving maintenance doses of digitalis, without signs and symptoms of heart failure and with normal cardiac indices and $\mathrm{A}-\mathrm{V}$ oxygen differences; Group IV, "normal output" congestive failure - two subjects, one normotensive and one hypertensive, with signs and symptoms of congestive heart failure but with normal cardiac indices and normal arterial-mixed venous oxygen differences. The four subjects, B.K., L.R., S.T. and $\mathrm{E}$. S., who were studied twice, once during congestive heart failure and again after recovery of compensation, appear in two groups according to their cardiovascular status on each occasion.

General response. There were no apparent differences between the subjects with congestive heart failure and the compensated cardiac and control subjects with respect to the amount of Arfonad ${ }^{\circledR}$ required to maintain vasodilatation, the speed with which vasodilatation occurred and the rapidity of return to the control state after stopping the drug (Table I). The dosage range was $0.35 \mathrm{mg}$. to $1.25 \mathrm{mg}$. per minute with the usual dose between $0.5 \mathrm{mg}$. to $1.0 \mathrm{mg}$. per minute. Two subjects (J.H. and J.M.), both of Group III, required much larger amounts, 3.0 and 2.0 mg. per minute, respectively. The rate of infusion of the drug was often increased by $0.25 \mathrm{mg}$. to $0.5 \mathrm{mg}$. per minute during the last half hour of vasodilatation in order to prevent the blood pressure from rising above the desired level. The time required to reach the desired level of vasodilatation varied considerably but averaged 25 to 30 minutes. The control state was reached on an average of 30 minutes after stopping the infusion.

During the vasodilatation the subjects with congestive heart failure seemed somewhat improved. They were quieter, less restless and less complaining. Cerebration seemed less active and they even dozed. Respirations were often more shallow and irregular. Yawning occurred infrequently. 
When ventricular premature contractions were previously present they became less frequent. Similar reactions occurred in subjects without congestive heart failure and, in addition, restlessness, tension and "inside nervousness" were encountered. After stopping the infusion of the drug, the initial condition of the patient rapidly returned.

Presentation of data. The primary and derived data are too voluminous to be presented for all subjects. The data presented are tabulated for each group of subjects and give the following information for each subject in a group: a) the average data of the control periods, $b$ ) the data of the period of maximum change during vasodilatation, $c$ ) the average data of the vasodilatation periods, $d$ ) the data of the postvasodilatation period, then the average data for all subjects of the group in the four categories above. The average data of the control $(a)$ and vasodilatation (c) periods are the averages of three periods except occasionally when experimental difficulties reduced the number to two and once to one. The period of maximum change during vasodilatation was usually the first vasodilatation period and only once later than the second. The difference between the average data of the three vasodilatation periods $(c)$ and the data of the period of maximum change $(b)$ indicates the failure of the initial changes to be maintained throughout the period of vasodilatation. The shortcomings of the comparison of individual data with average data are recognized. However, the presentation permits comparison of average data from control periods with average data during vasodilatation and comparison of the single "maximum change" period with the single postdilatation period, permitting, thereby, several ways of examining the effects produced by vasodilatation. These abridged data present with validity the changes indicated by the complete data.

Vascular pressures, vascular resistances, ventricular rate (Tables II to VII, Figures 1 and 2)

In all subjects of all four groups the blood pressure during Arfonad ${ }^{\left({ }^{\circledR}\right.}$ infusion fell in the systemic circuit, the pulmonic circuit and right heart; remained at the lowered level, or rose slightly, during the hour of vasodilatation; and returned

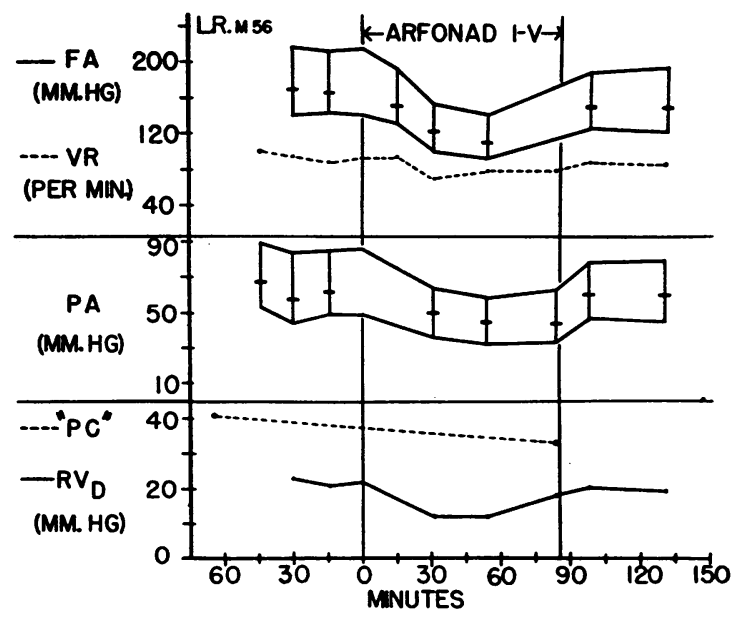

Fig. 1. Typical Serial Determinations of Vascular Pressures in a Representative Subject (L.R.) with Congestive Heart FaIlure

Rate of intravenous infusion of Arfonad $\$, 0.8 \mathrm{mg}$. per minute. FA designates femoral artery pressure; VR, ventricular rate; PA, pulmonary artery pressure; "PC," pulmonary "wedge" or "capillary" pressure; $\mathrm{RV}_{\mathrm{d}}$, right ventricular end diastolic pressure.

to, or well toward, the control levels after stopping the infusion. Although the actual decreases in the various systemic and pulmonic pressures were greater when the control pressures were elevated, the percentile decreases were of the same order of magnitude, usually between 20 and 30 per cent (Table VII), in both the greater and lesser circulations. An exception was the 60 per cent decrease in pulmonary "capillary" pressure in Groups II, III and IV. Although the elevated pressures due to congestive heart failure (right atrial, right ventricular, pulmonary arterial and pulmonary "capillary") were lowered decidedly, they did not fall to the normal range. Qualitatively and quantitatively the same degree of change in vascular pressures occurred in all four groups of subjects, and within each group normotensive and hypertensive subjects responded similarly.

Systemic vascular resistance decreased in all groups of subjects by about 30 per cent during vasodilatation and returned to control levels after the drug was discontinued. Exceptions were a 10 per cent decrease in systemic vascular resistance in the noncardiac and compensated subjects (Group III). Pulmonic vascular resistance, on the other hand, decreased, again by about 30 per cent, only in the the congestive heart 
SOBOL, KESSLER, RADER AND : EICHNA

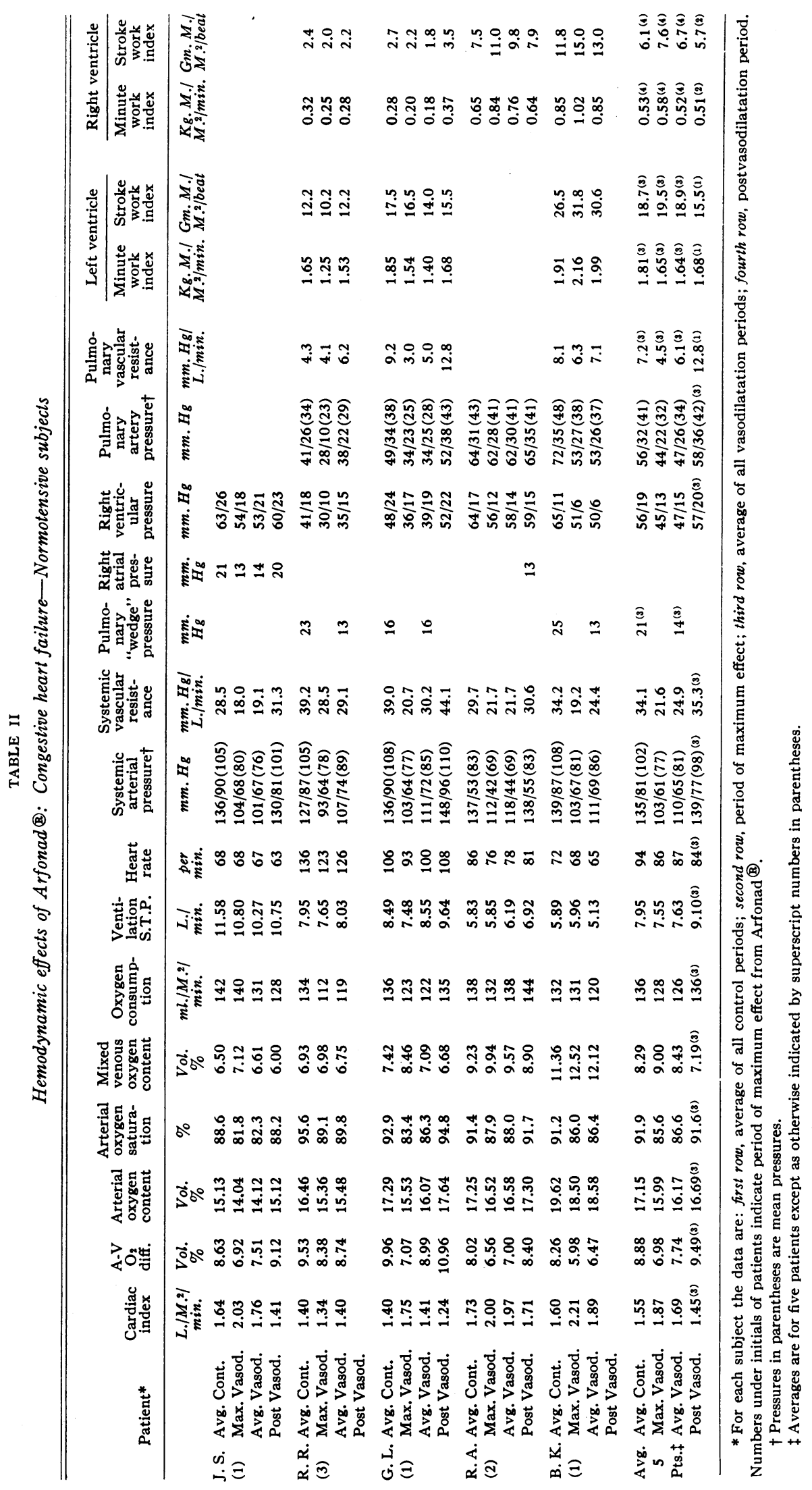




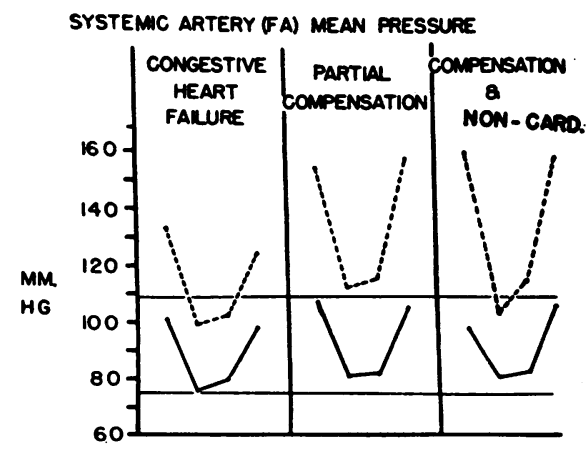

PULMONARY ARTERY (PAN MEAN PRESSURE

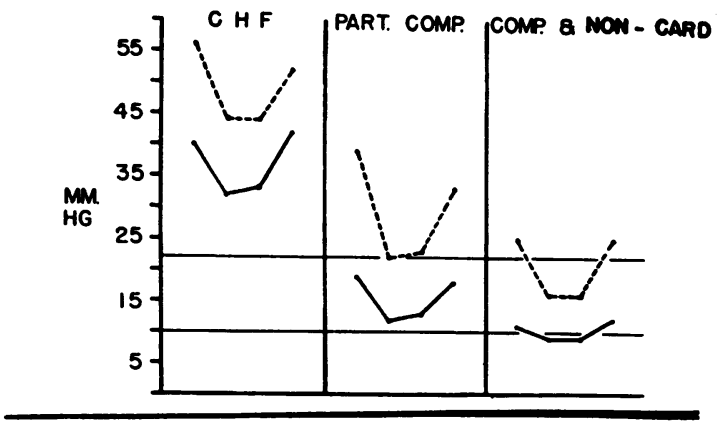

RA OR RV END DIASTOLIC PRESS.

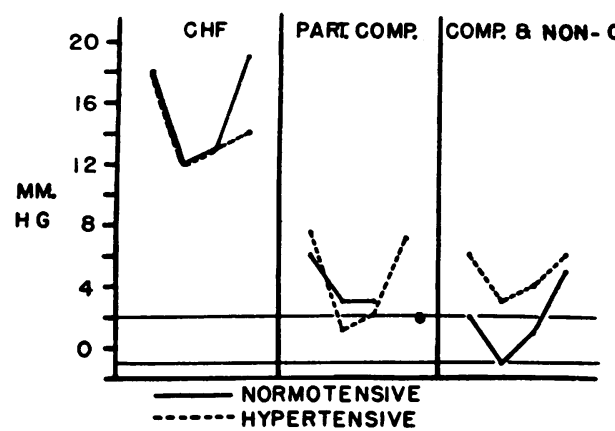

Fig. 2. EFfect of Intravenous Infusion of Arfonad on Vascular Pressures in Congestive Heart FaIluRe and in Cardiac Compensation

The data are the average data for all subjects in each group. For any line the first point is the average of the control periods, the second point is the period of maximum effect during vasodilatation, the third point is the average of the vasodilatation periods, the fourth point is the postvasodilatation period. In each panel the two horizontal lines indicate the range of normal values.

failure group and increased in each of the other three groups.

Ventricular rate decreased during the vasodilatation by 5 to 10 per cent in all subjects except in Group III where the rate tended to increase slightly, by 5 per cent. Unlike the vascular pressures and resistances, ventricular rate tended to remain below the control level after stopping the Arfonad ${ }^{\circledR}$ infusion.

The data indicate a generally similar decrease in vascular pressures and resistances in all groups of subjects, except for the changes in opposite direction in pulmonary vascular resistance.

Respiration and metabolism (Tables II to VII, Figure 3)

During vasodilatation the rhythm of respiration frequently became irregular but in all four groups of subjects the respiratory rate remained essentially unaltered. The minute volume of respiration showed inconsistent changes, tending to decrease slightly, 6 per cent, in subjects with heart failure (Group I) or partial compensation (Group II) and to increase by a comparable amount in noncardiac and compensated subjects (Group III). Except for lack of change in the two subjects with "normal output" failure (Group IV), the metabolic rate decreased slightly, 6 to 12 per cent, but consistently and significantly $(\mathrm{p}=<0.01)$ in the other subjects during vasodilatation and returned to the initial level upon discontinuing the vasodilator drug.

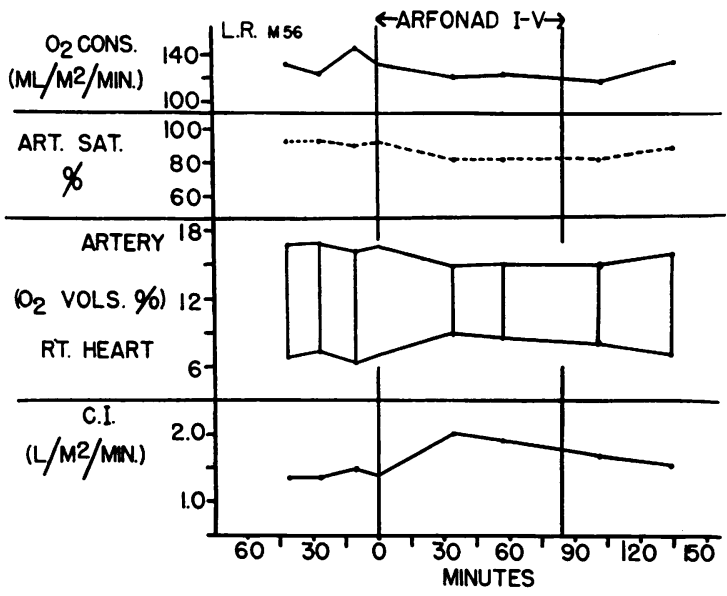

Fig. 3. Typical Serial Determinations of Blood Oxygen Content and Cardiac Output in a Representative Subject (L.R.) with Congestive Heart FAILURE

Rate of intravenous infusion of Arfonad ${ }^{\circledR}, 0.8 \mathrm{mg}$. per minute. $\mathrm{O}_{2}$ Cons. designates oxygen consumption; Art. Sat., arterial oxygen saturation; C.I., cardiac index. In the third panel from the top are indicated the oxygen content of blood of artery, top line; of mixed venous blood, lower line; and A-V oxygen difference, vertical connecting lines. 


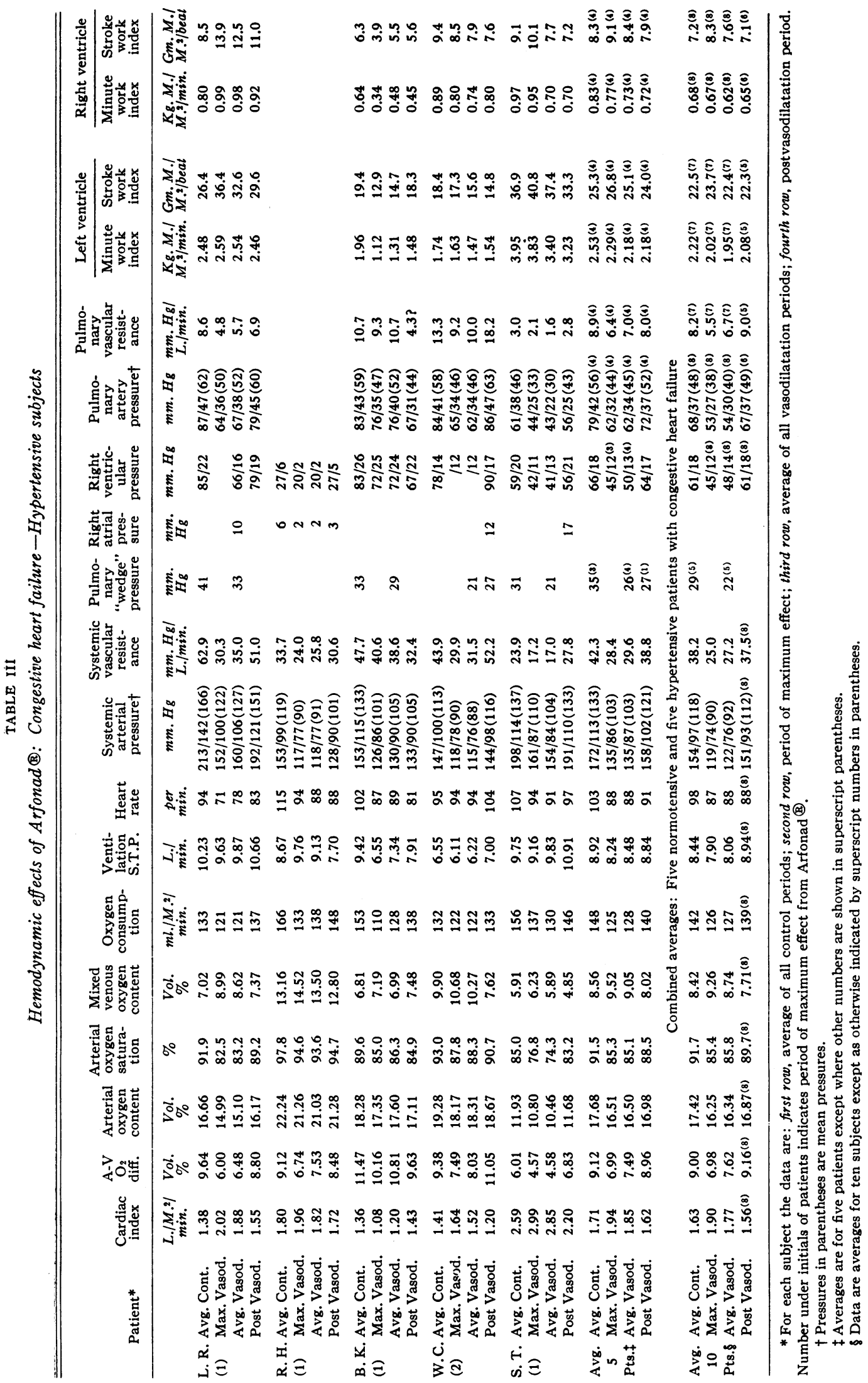


Cardiac output and blood oxygen contents (Tables II to VII, Figures 3 and 4)

During the fall in vascular pressures, cardiac output increased slightly, 15 per cent, but nevertheless definitely and consistently (8 of 10 subjects) in both the normotensive and hypertensive subjects in congestive heart failure (Group I). The increase appears significant: $p$ value for the 10 subjects lies between 0.05 and 0.02 . The increases did not, however, bring the cardiac outputs to normal values. In contrast, cardiac output fell in four of the five noncardiac and compensated cardiac subjects (Group III) and remained unchanged in one. Statistically, the average fall of 18 per cent appears significant: $\mathrm{p}$ value between 0.05 and 0.02 . The validity of these changes in cardiac output is indicated by the opposite, and again contrasting, changes in arterial-mixed venous oxygen difference, a better index of cardiac function than cardiac output in that the $\mathrm{A}-\mathrm{V}$ oxygen difference relates the blood supply (cardiac output) to the need for it (oxygen consumption). Thus, in congestive heart failure (Group I), the A-V oxygen difference decreased by 22 per cent ( $p$ value significant, less than 0.01 ); but again the final values were not in the normal range. In contrast, $\mathrm{A}-\mathrm{V}$ oxygen difference in the compensated cardiac and noncardiac subjects (Group III) changed variably (rose in three, decreased in one, unaltered in one) to give an average 5 per cent increase ( $p$ value a not significant 0.3 ). Furthermore, the decrease in A-V oxygen difference in congestive heart failure was associated with an average 5 to 10 per cent increase ( $p$ value between 0.1 and 0.05 ) in oxygen content of mixed venous blood. In contrast, an average 4 per cent decrease ( $p$ value between 0.1 and 0.05 ) in mixed venous oxygen content occurred in the noncardiac and compensated subjects. The changes in A-V oxygen difference were similar in normotensive and hypertensive subjects within a group.

As the period of vasodilatation progressed, the changes in cardiac output, $\mathrm{A}-\mathrm{V}$ oxygen difference and oxygen content of mixed venous blood tended to lessen and revert toward control values in the subjects with congestive heart failure (Tables II and III) but were better maintained at their altered levels in the compensated cardiac and noncardiac

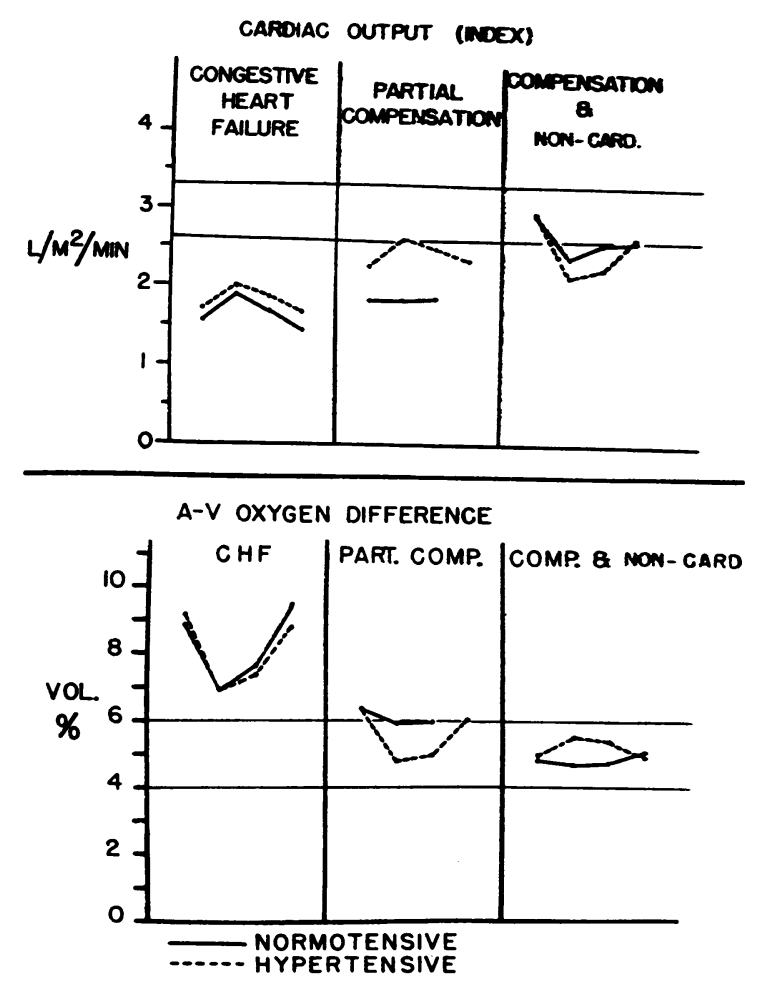

Fig. 4. Effect of Intravenous Infusion of ARFonad on Cardiac Output and A-V Oxygen Difference in Congestive Heart Failure and in Cardiac Compensation

Details of plotting are the same as those in Figure 2.

subjects (Table V). After withdrawal of Arfonad $^{\text {(ब) }}$ these functions returned to control values in the subjects with congestive failure but tended to remain at their altered values in the compensated cardiac and noncardiac subjects.

In the partially compensated subjects (Group II) the two hypertensive patients manifested changes similar to those in congestive heart failure; the two normotensive subjects developed no changes, nor did the two patients with "normal output" heart failure (Group IV).

In all subjects and at all levels of arterial oxygen content and arterial oxygen saturation, there occurred during vasodilatation a consistent fall ( $p$ value less than 0.01 ) in arterial oxygen content and oxygen saturation, amounting to 3 to 4 per cent in the noncardiac and compensated subjects and 6 to 8 per cent in the other three groups. These values returned well toward control levels after discontinuing the infusion of Arfonad ${ }^{(}$. 


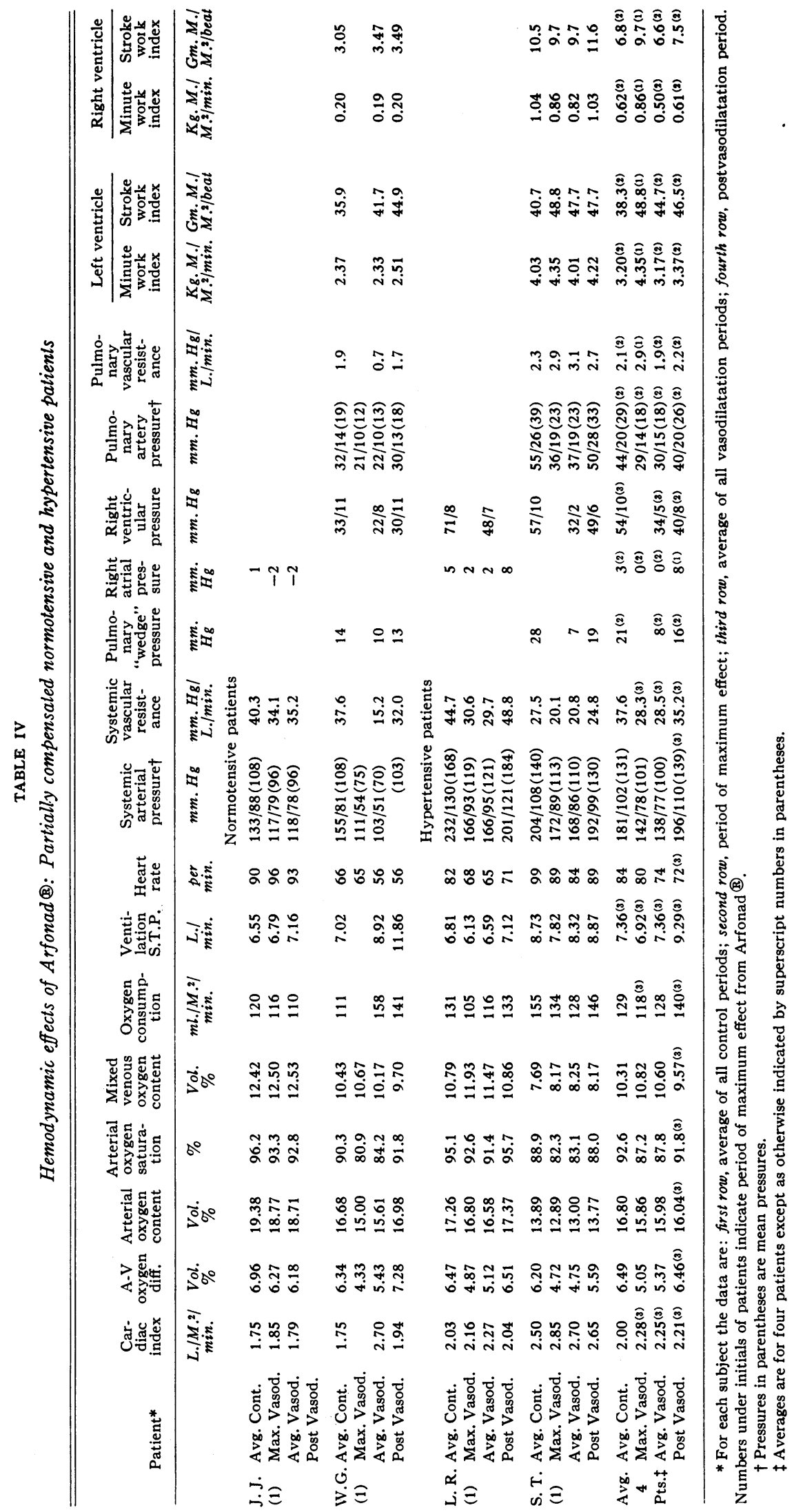


VASODILATATION IN CONGESTIVE HEART FAILURE

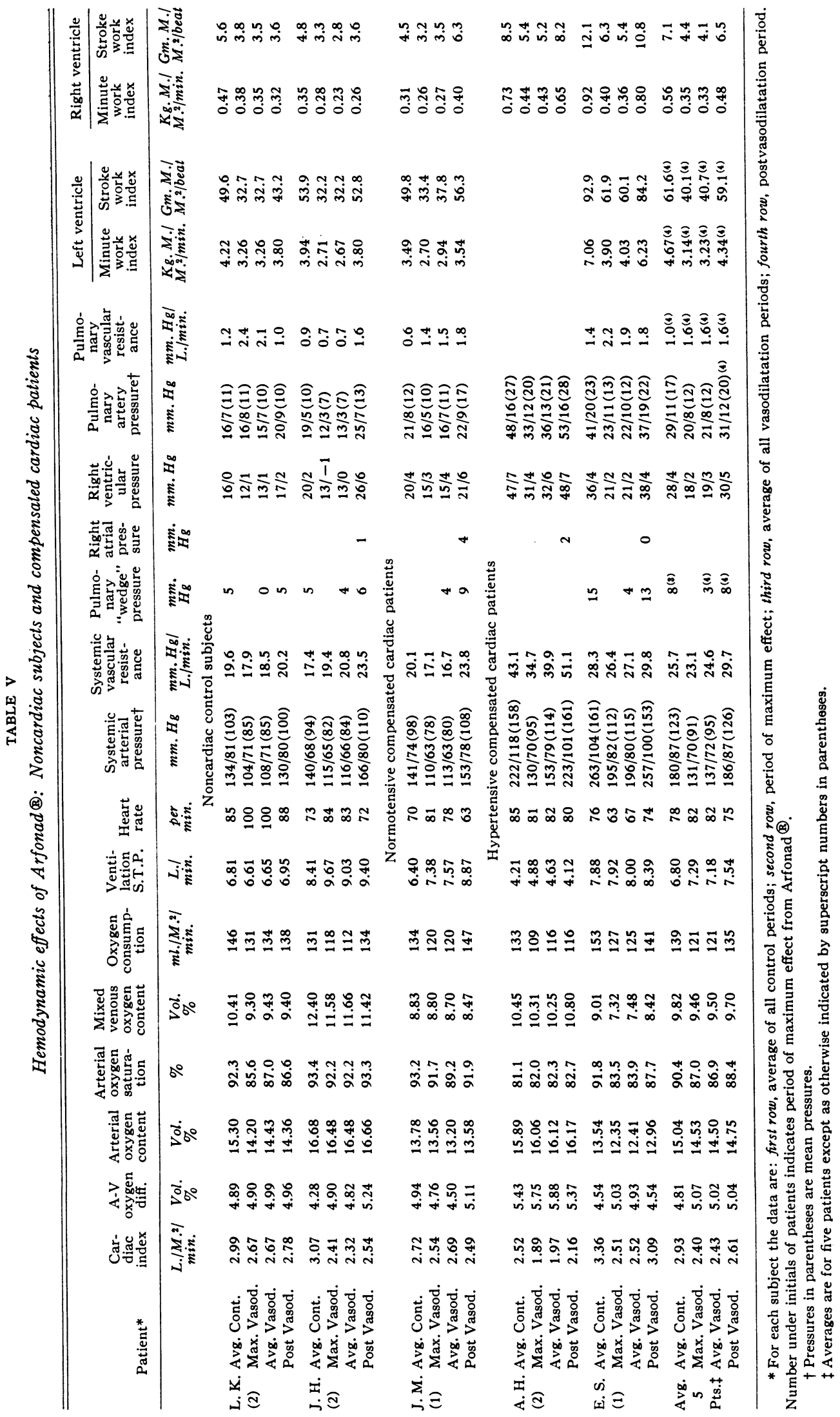


SOBOL, KESSLER, RADER AND EICHNA

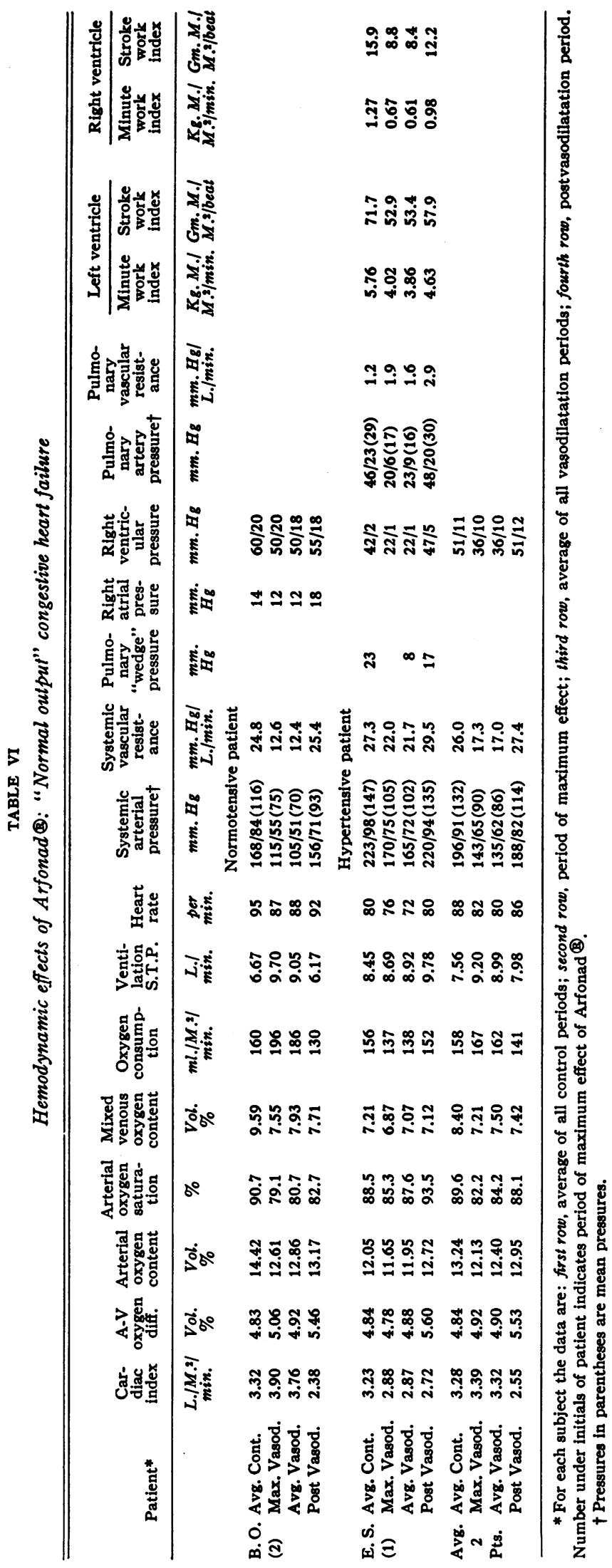




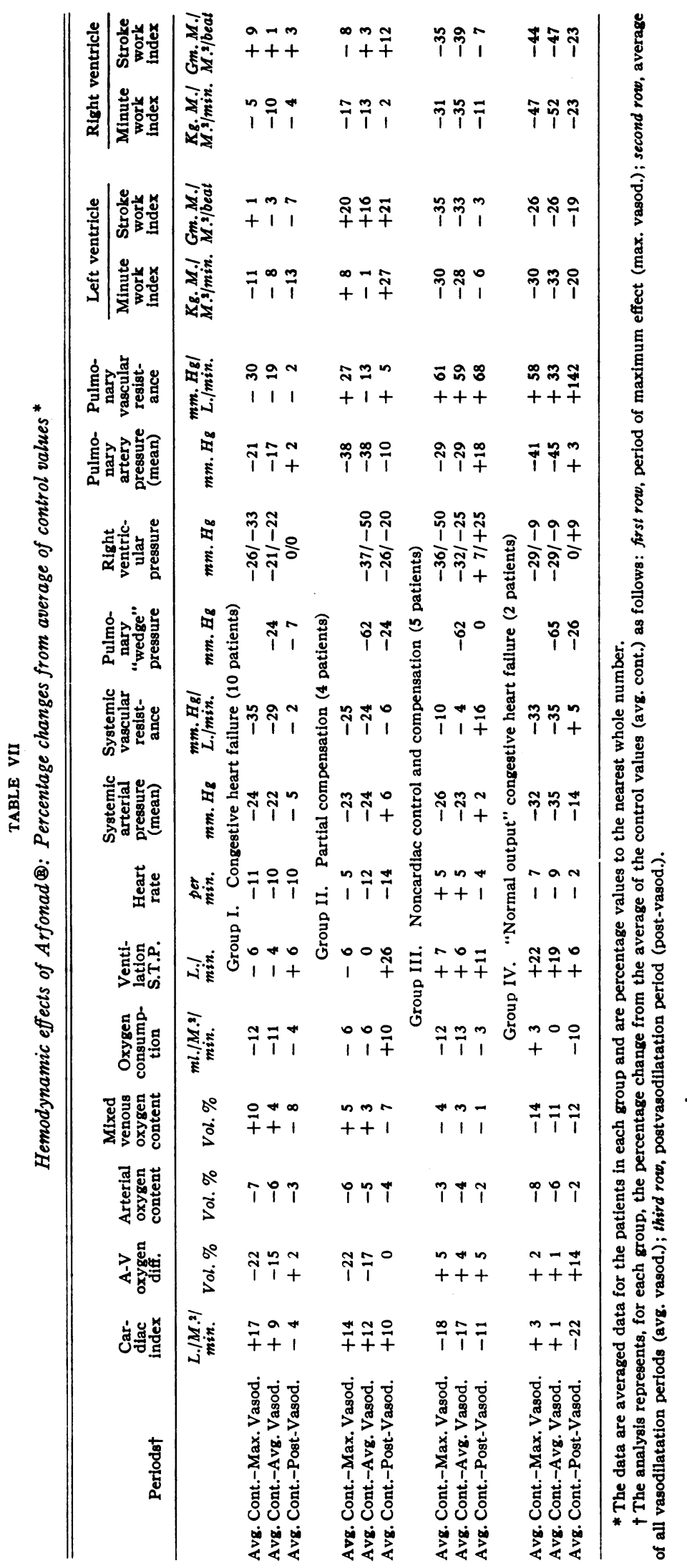




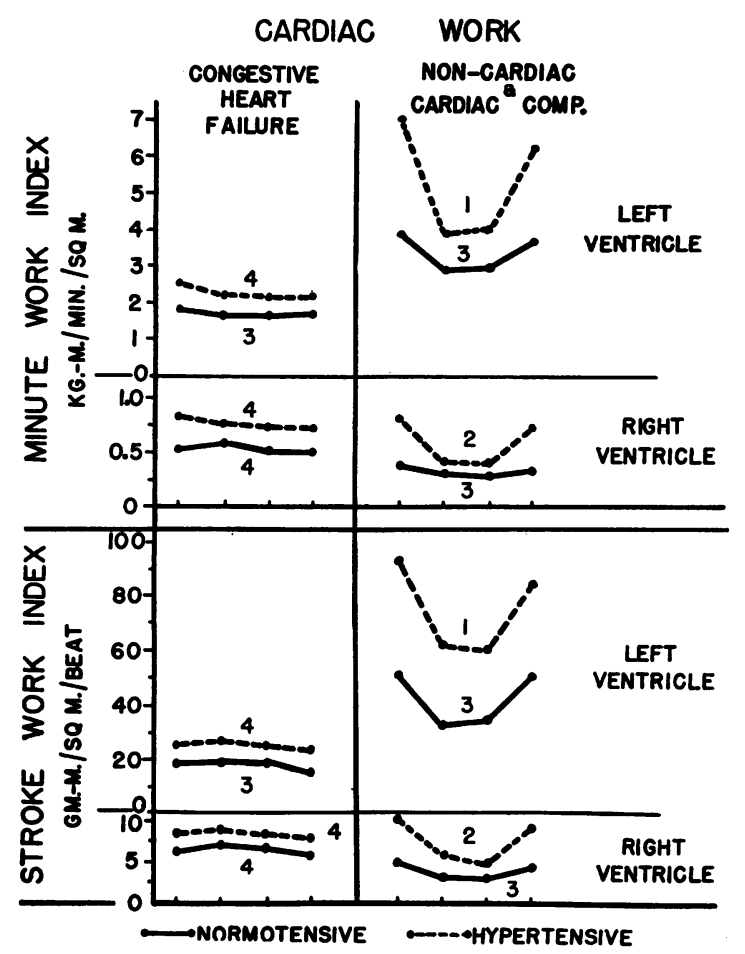

Fig. 5. Effect of Intravenous Infusion of Arfonad on Cardiac Work in Congestive Heart FailURE AND CaRdiac Compensation

Details of plotting are the same as in Figure 2, except that the horizontal line separates the data for the two ventricles and not the range of normal values. The numbers indicate subjects averaged for the adjacent lines.

\section{Cardiac work (Tables II to VII, Figure 5)}

In the patients with congestive heart failure (Group I) minute work index and stroke work index of both the left and right ventricle remained essentially unchanged, or perhaps decreased slightly, during the fall in vascular pressures and rise in cardiac output which accompanied vasodilatation (Tables II, III and VII). The lower values tended to persist in the postvasodilatation period. In contrast, in the compensated cardiac and noncardiac subjects (Group III) both left and right ventricular minute work index and stroke work index decreased, by 30 to 40 per cent, during the vasodilatation and tended to return to control values in the postvasodilatation period (Tables $\mathrm{V}$ and VII). Hypertensive and normotensive subjects in congestive heart failure had largely similar and equal responses (Figure 5). In the compensated cardiac and noncardiac subjects, the decreases in both cardiac work indices were greater in hypertensive than in normotensive subjects. Because of the small numbers of subjects in the several groups, statistical analysis of the data on cardiac work did not prove helpful.

In the one subject (hypertensive) with partial compensation (Group II) vasodilatation resulted in increases in minute work index ( 15 per cent) and stroke work index (25 per cent) of the left ventricle and decreases in both minute work index (15 per cent) and stroke work index ( 5 per cent) of the right ventricle (Table IV). The one (hypertensive) subject with "normal output" congestive failure (Group IV) developed marked decreases in both minute work and stroke work indices of the left (30 per cent) and right (45 per cent) ventricles (Table VI), a decided contrast with the results in low-output congestive heart failure.

\section{Renal functions and water and electrolyte excre- tions (Tables VIII to $X$, Figure 6)}

The changes in renal hemodynamic functions during vasodilatation were relatively small and variable. Glomerular filtration rate altered slightly and inconsistently in all groups, with decreases perhaps more frequent than increases. In subjects with congestive heart failure (Group I) renal plasma flow tended to increase (20 per

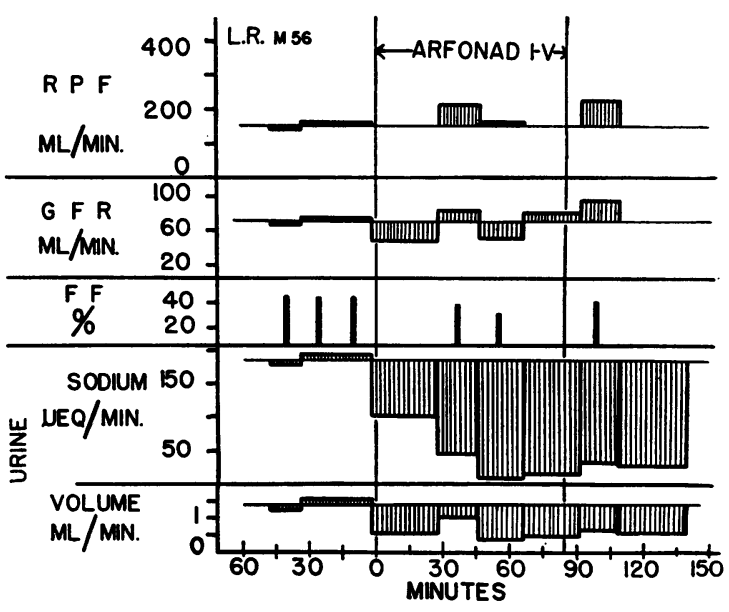

Fig. 6. Typical Serial Determinations of Renal Hemodynamics and Sodium and Water Excretions in a Representative Sưbject (L.R.) with Congestive HeART FaILURE

Rate of intravenous infusion of Arfonad $8,0.8 \mathrm{mg}$. per minute. RPF designates renal plasma flow; GFR, glomerular filtration rate; $\mathrm{FF}$, filtration fraction. 
TABLE VIII

Effects of Arfonad (B) on renal hemodynamics and urinary excretions: Congestive heart failure

\begin{tabular}{|c|c|c|c|c|c|c|c|c|c|c|}
\hline & Patient* & $\begin{array}{l}\text { Glomer- } \\
\text { ular } \\
\text { filtration } \\
\text { rate }\end{array}$ & $\begin{array}{c}\text { Renal } \\
\text { plasma } \\
\text { flow }\end{array}$ & $\begin{array}{l}\text { Filtra- } \\
\text { tion- } \\
\text { fraction }\end{array}$ & $\begin{array}{l}\text { Renal } \\
\text { blood } \\
\text { flow }\end{array}$ & $\begin{array}{c}\text { Renal } \\
\text { fraction } \\
\text { of cardiac } \\
\text { output }\end{array}$ & $\begin{array}{l}\text { Renal } \\
\text { vascular } \\
\text { resist- } \\
\text { ance }\end{array}$ & $\begin{array}{l}\text { Urine } \\
\text { output }\end{array}$ & $\begin{array}{c}\text { Urinary } \\
\text { sodium } \\
\text { excretion }\end{array}$ & $\begin{array}{c}\text { Urinary } \\
\text { potassium } \\
\text { excretion }\end{array}$ \\
\hline & & ml./min. & ml. $/ \min$. & $\%$ & $\operatorname{ml.} / \min$. & $\%$ & $\underset{L . / m i n}{\operatorname{mm} . \boldsymbol{H} g}$ & ml./min. & $\mu E q . / m i n$ & $\mu E q . / \min$. \\
\hline \multicolumn{11}{|c|}{ Normotensive patients } \\
\hline $\begin{array}{l}\text { G. L. } \\
\text { (1) }\end{array}$ & $\begin{array}{l}\text { Avg. Cont. } \\
\text { Max. Vasod. } \\
\text { Avg. Vasod. } \\
\text { Post Vasod. }\end{array}$ & & $\begin{array}{l}165 \\
214 \\
156 \\
203\end{array}$ & & $\begin{array}{l}262 \\
340 \\
248 \\
322\end{array}$ & $\begin{array}{r}9.9 \\
11.5 \\
10.3 \\
15.4\end{array}$ & $\begin{array}{l}376 \\
176 \\
284 \\
273\end{array}$ & $\begin{array}{l}0.4 \\
0.7 \\
0.5 \\
0.6\end{array}$ & $\begin{array}{l}<0.2 \\
<0.2 \\
<0.2 \\
<0.2\end{array}$ & $\begin{array}{l}26 \\
34 \\
26 \\
38\end{array}$ \\
\hline $\begin{array}{l}\text { B. K. } \\
\text { (1) }\end{array}$ & $\begin{array}{l}\text { Avg. Cont. } \\
\text { Max. Vasod. } \\
\text { Avg. Vasod. } \\
\text { Post Vasod. }\end{array}$ & $\begin{array}{l}54 \\
51 \\
53\end{array}$ & $\begin{array}{l}162 \\
180 \\
184\end{array}$ & $\begin{array}{l}33 \\
28 \\
28\end{array}$ & $\begin{array}{l}337 \\
375 \\
384\end{array}$ & $\begin{array}{r}11.9 \\
9.5 \\
11.7\end{array}$ & $\begin{array}{l}289 \\
200 \\
207\end{array}$ & $\begin{array}{l}0.9 \\
0.6 \\
0.8\end{array}$ & $\begin{array}{l}5 \\
1 \\
2\end{array}$ & $\begin{array}{l}53 \\
46 \\
54\end{array}$ \\
\hline \multicolumn{11}{|c|}{ Hypertensive patients } \\
\hline$\underset{(2)}{\text { L. R. }}$ & $\begin{array}{l}\text { Avg. Cont. } \\
\text { Max. Vasod. } \\
\text { Avg. Vasod. } \\
\text { Post Vasod. }\end{array}$ & $\begin{array}{l}71 \\
51 \\
76\end{array}$ & $\begin{array}{l}156 \\
162 \\
200\end{array}$ & $\begin{array}{l}46 \\
32 \\
37\end{array}$ & & & & $\begin{array}{l}1.4 \\
0.3 \\
0.7 \\
0.6\end{array}$ & $\begin{array}{r}187 \\
<10 \\
30 \\
29\end{array}$ & $\begin{array}{l}73 \\
37 \\
50 \\
45\end{array}$ \\
\hline$\underset{(2)}{\text { R. } H .}$ & $\begin{array}{l}\text { Avg. Cont. } \\
\text { Max. Vasod. } \\
\text { Avg. Vasod. } \\
\text { Post Vasod. }\end{array}$ & & $\begin{array}{l}264 \\
381 \\
328 \\
254\end{array}$ & & & & & $\begin{array}{l}1.1 \\
1.1 \\
0.8 \\
0.8\end{array}$ & $\begin{array}{l}101 \\
144 \\
115 \\
102\end{array}$ & \\
\hline $\begin{array}{l}\text { B. K. } \\
\text { (1) }\end{array}$ & $\begin{array}{l}\text { Avg. Cont. } \\
\text { Max. Vasod. } \\
\text { Avg. Vasod. } \\
\text { Post Vasod. }\end{array}$ & $\begin{array}{l}60 \\
76 \\
74 \\
69\end{array}$ & $\begin{array}{l}125 \\
157 \\
138 \\
131\end{array}$ & $\begin{array}{l}46 \\
48 \\
54 \\
52\end{array}$ & $\begin{array}{l}223 \\
280 \\
247 \\
234\end{array}$ & $\begin{array}{r}8.6 \\
14.4 \\
11.7 \\
9.1\end{array}$ & $\begin{array}{l}430 \\
243 \\
320 \\
355\end{array}$ & $\begin{array}{l}0.9 \\
0.8 \\
0.9 \\
0.9\end{array}$ & $\begin{array}{r}15 \\
7 \\
4 \\
8\end{array}$ & $\begin{array}{l}5 \\
5 \\
5 \\
5\end{array}$ \\
\hline $\begin{array}{l}\text { S. T. } \\
(2)\end{array}$ & $\begin{array}{l}\text { Avg. Cont. } \\
\text { Max. Vasod. } \\
\text { Avg. Vasod. } \\
\text { Post Vasod. }\end{array}$ & $\begin{array}{l}17 \\
14 \\
13 \\
20\end{array}$ & $\begin{array}{l}59 \\
53 \\
54 \\
60\end{array}$ & $\begin{array}{l}29 \\
26 \\
23 \\
34\end{array}$ & $\begin{array}{l}77 \\
72 \\
74 \\
82\end{array}$ & $\begin{array}{l}1.6 \\
1.2 \\
1.3 \\
2.0\end{array}$ & $\begin{array}{l}1,562 \\
1,194 \\
1,228 \\
1,366\end{array}$ & $\begin{array}{l}2.0 \\
1.1 \\
1.1 \\
1.7\end{array}$ & $\begin{array}{r}187 \\
83 \\
85 \\
134\end{array}$ & $\begin{array}{l}28 \\
26 \\
30 \\
44\end{array}$ \\
\hline $\begin{array}{c}\text { Avg. } \\
6 \\
\text { Pts. }\end{array}$ & $\begin{array}{l}\text { Avg. Cont. } \\
\text { Max. Vasod. } \\
\text { Avg. Vasod. } \\
\text { Post Vasod. }\end{array}$ & $\begin{array}{l}50^{(4)} \\
48^{(4)} \\
54^{(4)} \\
45^{(2)}\end{array}$ & $\begin{array}{l}155 \\
191 \\
177 \\
162^{(4)}\end{array}$ & $\begin{array}{l}38^{(4)} \\
33^{(4)} \\
36^{(4)} \\
43^{(2)}\end{array}$ & $\begin{array}{l}225^{(4)} \\
267^{(4)} \\
238^{(4)} \\
213^{(3)}\end{array}$ & $\begin{array}{l}8.0^{(4)} \\
9.2^{(4)} \\
8.8^{(4)} \\
8.9^{(3)}\end{array}$ & $\begin{array}{l}664^{(4)} \\
453^{(4)} \\
510^{(4)} \\
664^{(3)}\end{array}$ & $\begin{array}{l}1.1 \\
0.8 \\
0.8 \\
0.9^{(5)}\end{array}$ & $\begin{array}{l}82 \\
41 \\
46 \\
73^{(6)}\end{array}$ & $\begin{array}{l}37^{(5)} \\
30^{(5)} \\
33^{(5)} \\
33^{(4)}\end{array}$ \\
\hline \multicolumn{11}{|c|}{ "Normal output" congestive heart failure } \\
\hline $\begin{array}{l}\text { B. } O . \\
\text { (1) }\end{array}$ & $\begin{array}{l}\text { Avg. Cont. } \\
\text { Max. Vasod. } \\
\text { Avg. Vasod. } \\
\text { Post Vasod. }\end{array}$ & $\begin{array}{l}56 \\
35 \\
40 \\
50\end{array}$ & $\begin{array}{l}162 \\
138 \\
162 \\
165\end{array}$ & $\begin{array}{l}34 \\
25 \\
25 \\
30\end{array}$ & $\begin{array}{l}249 \\
212 \\
248 \\
254\end{array}$ & $\begin{array}{l}6.1 \\
4.7 \\
5.3 \\
8.6\end{array}$ & $\begin{array}{l}410 \\
259 \\
236 \\
295\end{array}$ & $\begin{array}{l}5.6 \\
0.4 \\
0.7 \\
3.0\end{array}$ & $\begin{array}{r}867 \\
65 \\
106 \\
514\end{array}$ & $\begin{array}{r}<30 \\
16 \\
26 \\
48\end{array}$ \\
\hline
\end{tabular}

* For each subject the data are: first row, average of all control periods; second row, period of maximum effect; third row, average of all vasodilatation periods; fourth row, postvasodilatation period. Number under initials of patients indicates period of maximum effect of Arfonad ${ }^{\circledR}$.

$\dagger$ Averages are for six patients except as otherwise indicated by superscript numbers in parentheses.

cent) and similar, if slightly less marked, rises occurred in renal blood flow and in the renal fraction (Tables VIII and X). No similar changes occurred in the other three groups of subjects, where decreases in these three renal hemodynamic functions were more common than increases. However, consistent decreases in filtration fraction, 10 to 15 per cent, and in renal vascular resistance, 15 to 30 per cent, occurred in all four groups of subjects and to approximately the same extent. In the few patients studied no difference was noted between the normotensive and hypertensive subjects.

In all four groups the renal excretion of water and sodium, and less markedly and regularly of potassium, decreased during the period of vasodilatation, usually by about 30 per cent, but by as much as 80 to 90 per cent for water and sodium when their initial excretions were large. The decrease in urine volume was usually associ- 
ated with a decrease in glomerular filtration but falls in electrolyte excretion occurred without appreciable changes in glomeruluar filtration. The water and electrolyte excretions remained decreased, at least to some degree, during the postvasodilatation period, when cardiovascular dynamics had already returned to, or well toward, control values.

\section{DISCUSSION}

On the whole the patients, even with severe congestive heart failure, tolerated surprisingly well the irksome and long procedures imposed by this study. The complexity of the procedures, the variations in circulatory state between patients even of the same group, and the difficulty of obtaining a similar circulatory state or change of state during vasodilatation probably contributed to the variability of the data obtained. This variability and the relatively few subjects studied do not permit strict quantitative relationships to be drawn between the various functions. Nevertheless, the qualitative changes which emerged appear valid.

\section{Nature of the cardiovascular and renal responses during vasodilatation}

The present observations substantiate previously reported studies, usually of individual or few functions, which indicate that primary vasodilatation, induced by various vasodilating agents, produces changes similar to those here observed: decreases in pressure in all parts of the compensated circulatory system in both normal and hypertensive circulations (23-26) and in congestive heart failure $(23-25,27-29)$, a rise in cardiac output in congestive heart failure $(23-25,27)$ but a fall in output in the normal circulations (23, $25,26)$ and a decrease in water and electrolyte excretions, associated with inconsistent changes in renal hemodynamics, in all circulatory states. $(23,25,26,30,31)$. Through repeated, integrated and simultaneous determinations of multiple functions, the present observations permit a more direct correlation of the changes in the several functions.

One question in the present study was to examine whether differences in vascular tonus between normal and congested circulations might be disclosed by the need for different amounts of

TABLE IX

Effects of Arfonad ${ }^{\circledR}$ on renal hemodynamics and urinary excretions: Noncardiac subjects and partially compensated cardiac patients

\begin{tabular}{|c|c|c|c|c|c|c|c|c|c|c|}
\hline & Patient* & $\begin{array}{c}\text { Glomer- } \\
\text { ular } \\
\text { filtration } \\
\text { rate }\end{array}$ & $\begin{array}{c}\text { Renal } \\
\text { plasma } \\
\text { flow }\end{array}$ & $\begin{array}{c}\text { Filtra- } \\
\text { tion } \\
\text { fraction }\end{array}$ & $\begin{array}{l}\text { Renal } \\
\text { blood } \\
\text { flow }\end{array}$ & $\begin{array}{c}\text { Renal } \\
\text { fraction } \\
\text { of cardiac } \\
\text { output }\end{array}$ & $\begin{array}{l}\text { Renal } \\
\text { vascular } \\
\text { resist- } \\
\text { ance }\end{array}$ & $\begin{array}{c}\text { Urine } \\
\text { output }\end{array}$ & $\begin{array}{c}\text { Urinary } \\
\text { sodium } \\
\text { excretion }\end{array}$ & $\begin{array}{c}\text { Urinary } \\
\text { potassium } \\
\text { excretion }\end{array}$ \\
\hline & & ml./min. & ml./min. & $\%$ & $\operatorname{ml} . / \min$. & $\%$ & $\underset{L . \mid \min }{\operatorname{mm} .}$ & ml./min. & $\mu E q . / m i n$. & $\mu E q . / \min$. \\
\hline \multicolumn{11}{|c|}{ Noncardiac control subject } \\
\hline$\underset{(1)}{\text { L. K. }}$ & $\begin{array}{l}\text { Avg. Cont. } \\
\text { Max. Vasod. } \\
\text { Avg. Vasod. } \\
\text { Post Vasod. }\end{array}$ & $\begin{array}{l}102 \\
100 \\
104 \\
113\end{array}$ & $\begin{array}{l}539 \\
584 \\
571 \\
581\end{array}$ & $\begin{array}{l}19 \\
17 \\
18 \\
19\end{array}$ & $\begin{array}{l}842 \\
885 \\
866 \\
881\end{array}$ & $\begin{array}{l}16.1 \\
21.2 \\
18.4 \\
18.1\end{array}$ & $\begin{array}{r}124 \\
106 \\
99 \\
111\end{array}$ & $\begin{array}{l}0.5 \\
0.4 \\
0.4 \\
0.6\end{array}$ & $\begin{array}{r}134 \\
60 \\
64 \\
30\end{array}$ & $\begin{array}{l}41 \\
46 \\
45 \\
33\end{array}$ \\
\hline \multicolumn{11}{|c|}{ Normotensive partially compensated cardiac patient } \\
\hline $\mathrm{J}_{\text {(i) }} \mathrm{J}$. & $\begin{array}{l}\text { Avg. Cont. } \\
\text { Max. Vasod. } \\
\text { Avg. Vasod. } \\
\text { Post Vasod. }\end{array}$ & $\begin{array}{l}67 \\
61 \\
66\end{array}$ & $\begin{array}{l}209 \\
196 \\
214\end{array}$ & $\begin{array}{l}32 \\
31 \\
31\end{array}$ & $\begin{array}{l}362 \\
356 \\
390\end{array}$ & $\begin{array}{l}13.5 \\
12.6 \\
14.2\end{array}$ & $\begin{array}{l}299 \\
275 \\
252\end{array}$ & $\begin{array}{l}1.2 \\
1.0 \\
1.1\end{array}$ & $\begin{array}{l}83 \\
73 \\
76\end{array}$ & $\begin{array}{l}61 \\
51 \\
56\end{array}$ \\
\hline \multicolumn{11}{|c|}{ Hypertensive partially compensated cardiac patient } \\
\hline$\underset{\text { (i) }}{\text { L. R. }}$ & $\begin{array}{l}\text { Avg. Cont. } \\
\text { Max. Vasod. } \\
\text { Avg. Vasod. } \\
\text { Post Vasod. }\end{array}$ & $\begin{array}{r}101 \\
56 \\
70\end{array}$ & $\begin{array}{l}251 \\
157 \\
211\end{array}$ & $\begin{array}{l}41 \\
36 \\
34\end{array}$ & & & & $\begin{array}{l}6.3 \\
0.4 \\
0.4 \\
1.1\end{array}$ & $\begin{array}{r}619 \\
28 \\
19 \\
74\end{array}$ & $\begin{array}{l}79 \\
43 \\
56 \\
80\end{array}$ \\
\hline
\end{tabular}

* For each subject the data are: first row, average of all control periods; second row, period of maximum effect; third row, average of all vasodilatation periods; fourth row, postvasodilatation period. Number under initials of patients. indicates period of maximum effect of Arfonad (8. 
VASODILATATION IN CONGESTIVE HEART FAILURE

TABLE $X$

Renal hemodynamic and urinary effects of Arfonad (8: Percentage changes from average control values *

\begin{tabular}{|c|c|c|c|c|c|c|c|c|c|}
\hline Periods $†$ & $\begin{array}{l}\text { Glomer- } \\
\text { ular } \\
\text { filtration } \\
\text { rate }\end{array}$ & $\begin{array}{c}\text { Renal } \\
\text { plasma } \\
\text { flow }\end{array}$ & $\begin{array}{c}\text { Filtra- } \\
\text { tion } \\
\text { fraction }\end{array}$ & $\begin{array}{l}\text { Renal } \\
\text { blood } \\
\text { flow }\end{array}$ & $\begin{array}{c}\text { Renal } \\
\text { fraction } \\
\text { of cardiac } \\
\text { output }\end{array}$ & $\begin{array}{l}\text { Renal } \\
\text { vascular } \\
\text { resist- } \\
\text { ance }\end{array}$ & $\begin{array}{c}\text { Urine } \\
\text { output }\end{array}$ & $\begin{array}{c}\text { Urinary } \\
\text { sodium } \\
\text { excretion }\end{array}$ & $\begin{array}{l}\text { Urinary } \\
\text { potassium } \\
\text { excretion }\end{array}$ \\
\hline & ml./min. & mb./min. & $\%$ & ml./min. & $\%$ & $\underset{L . \mid \text { min. }}{\operatorname{mmg} .}$ & ml./min. & $\mu E q . / \min$. & $\mu E q_{.} / \min$. \\
\hline \multicolumn{10}{|c|}{ Group I. Congestive heart failure ( 6 patients) } \\
\hline $\begin{array}{l}\text { Avg. Cont.-Max. Vasod. } \\
\text { Avg. Cont.-Avg. Vasod. } \\
\text { Avg. Cont.-Post-Vasod. }\end{array}$ & $\begin{array}{l}-4 \\
+8 \\
-10\end{array}$ & $\begin{array}{l}+23 \\
+11 \\
+4\end{array}$ & $\begin{array}{l}-13 \\
-5 \\
+13\end{array}$ & $\begin{array}{l}+19 \\
+6 \\
+5\end{array}$ & $\begin{array}{l}+15 \\
+10 \\
+11\end{array}$ & $\begin{array}{r}-32 \\
-23 \\
0\end{array}$ & $\begin{array}{l}-31 \\
-32 \\
-20\end{array}$ & $\begin{array}{l}-50 \\
-44 \\
-11\end{array}$ & $\begin{array}{l}-19 \\
-11 \\
-11\end{array}$ \\
\hline \multicolumn{10}{|c|}{ Group II. Partial compensation (2 patients) } \\
\hline $\begin{array}{l}\text { Avg. Cont.-Max. Vasod. } \\
\text { Avg. Cont.-Avg. Vasod. } \\
\text { Avg. Cont.-Post-Vasod. }\end{array}$ & $\begin{array}{l}-30 \\
-19\end{array}$ & $\begin{array}{l}-23 \\
-8\end{array}$ & $\begin{array}{r}-6 \\
-11\end{array}$ & $\begin{array}{r}-2 \\
+8\end{array}$ & $\begin{array}{l}-7 \\
+5\end{array}$ & $\begin{array}{l}-8 \\
-16\end{array}$ & $\begin{array}{l}-81 \\
-80 \\
-71\end{array}$ & $\begin{array}{l}-86 \\
-86 \\
-79\end{array}$ & $\begin{array}{l}-33 \\
-20 \\
+14\end{array}$ \\
\hline \multicolumn{10}{|c|}{ Group III. Noncardiac control and compensation (1 patient) } \\
\hline $\begin{array}{l}\text { Avg. Cont.-Max. Vasod. } \\
\text { Avg. Cont.-Avg. Vasod. } \\
\text { Avg. Cont.-Post-Vasod. }\end{array}$ & $\begin{array}{l}-2 \\
+4 \\
+13\end{array}$ & $\begin{array}{l}+8 \\
+6 \\
+8\end{array}$ & $\begin{array}{r}-10 \\
-5 \\
0\end{array}$ & $\begin{array}{l}+5 \\
+3 \\
+5\end{array}$ & $\begin{array}{l}+32 \\
+14 \\
+12\end{array}$ & $\begin{array}{l}-14 \\
-20 \\
-10\end{array}$ & $\begin{array}{l}-30 \\
-26 \\
+13\end{array}$ & $\begin{array}{l}-55 \\
-52 \\
-78\end{array}$ & $\begin{array}{l}+12 \\
+10 \\
-19\end{array}$ \\
\hline \multicolumn{10}{|c|}{ Group IV. "Normal output" congestive heart failure (1 patient) } \\
\hline $\begin{array}{l}\text { Avg. Cont.-Max. Vasod. } \\
\text { Avg. Cont.-Avg. Vasod. } \\
\text { Avg. Cont.-Post-Vasod. }\end{array}$ & $\begin{array}{l}-38 \\
-29 \\
-11\end{array}$ & $\begin{array}{r}-15 \\
0 \\
+2\end{array}$ & $\begin{array}{l}-26 \\
-26 \\
-12\end{array}$ & $\begin{array}{r}-15 \\
0 \\
+2\end{array}$ & $\begin{array}{l}-23 \\
-13 \\
+41\end{array}$ & $\begin{array}{l}-37 \\
-42 \\
-28\end{array}$ & $\begin{array}{l}-93 \\
-88 \\
-47\end{array}$ & $\begin{array}{l}-92 \\
-88 \\
-41\end{array}$ & \\
\hline
\end{tabular}

* The data are averaged data for the patients in each group and are percentage values to the nearest whole number.

$\dagger$ The analysis represents, for each group, the percentage change from the average of the control values (avg. cont.) as follows: first row, period of maximum effect (max. vasod.); second row, average of all vasodilatation periods (avg. vasod.); third row, postvasodilatation period (post-vasod.).

vasodilator agent in the two states. The data do not provide an answer. The two noncardiac subjects required the largest amounts of Arfonad used. The same amount of Arfonad ${ }^{\circ}$ appeared to produce larger actual falls in vascular pressures in congestive heart failure but the percentile changes in pressure were as great, and even greater, in the normal circulations, particularly in regard to residual or filling pressures.

The fall in systemic and renal vascular resistances during both rising and falling cardiac outputs and in both the normal circulation and in congestive heart failure indicates that Arfonad ${ }^{(0)}$ produced primary vasodilatation of the systemic vascular circuit. A similar fall in pulmonary vascular resistance in congestive heart failure suggests a primary dilatation of the pulmonary vasculature and not solely a redistribution of blood from the pulmonary vascular bed into the concomitantly dilating systemic vessels (32). Arfonad ${ }^{8}$ is considered to be primarily a ganglionic blocking agent and the decreases in vascular resistances may, at first, be taken as evidence that the vasodilatations are of neurogenic origin. However, a direct dilator action of Arfonad ${ }^{\circledR}$ on blood vessels has been reported (13). The data cannot, therefore, resolve the question of the existence of sympathetic innervation of the pulmonary vessels. This is particularly so since pulmonary vascular resistance actually rose in the more normal circulations (Group III), presumably in response to the distribution of blood away from the lung into the systemic vascular bed.

No explanation is apparent for the unexpected fall in oxygen consumption during vasodilatation, unless the drug actually lowers the metabolic rate. It is also possible that tissue metabolic rate did not change and that the observed low pulmonary uptake of oxygen was supplemented by additional and unaccounted oxygen from other sources. No such sources are apparent.

The consistently lowered arterial oxygen content during vasodilatation was associated with no significant change in respiratory rate or minute volume of respiration. Accordingly, it is unlikely that impaired alveolar ventilation with decreased alveolar oxygen tension was responsible for the arterial unsaturation. An intriguing possible ex- 
planation might be the opening up during vasodilatation of communications between pulmonary arterial and pulmonary venous channels, by passing the alveoli and permitting a greater degree of venous admixture.

Since hypoxia has been shown to induce hemodynamic effects, the fall in arterial oxygen saturation during vasodilatation introduces a complicating factor in the analysis of the results obtained. In noncardiac subjects, arterial oxygen saturation down to 80 or 82 per cent is tolerated without change in cardiac output, while hypoxia of greater degree causes an increase in cardiac output (33-35). In the present 21 observations arterial oxygen saturation during vasodilatation fell to 82 per cent or below only six times; 12 times the saturation remained above 85 per cent and three times above 90 per cent. It appears unlikely that this degree of hypoxia influenced the cardiac output in the noncardiac and compensated cardiac subjects. Two further points support this conclusion: The change in cardiac output during the hypoxia was opposite (a fall) to the expected increases induced by significant hypoxia and the degree of change in cardiac output was not related to the extent of fall in arterial oxygen saturation. Data indicating the effect of hypoxia on cardiac function of patients with congestive heart failure were not located. In the present study the increase in cardiac output during vasodilatation in congestive failure patients is considered to be unaffected by the associated hypoxia, largely for the reason already cited, but particularly because the induced hypoxia was rarely down to 80 per cent arterial oxygen saturation and because the changes in cardiac output were much the same whether arterial oxygen saturation fell considerably (to 82 per cent) or only minimally (to 88 per cent).

\section{Comparison of effects produced by vasodilatation with effects produced by digitalis}

In congestive heart failure, some of the effects produced by intravenously administered Arfonad ${ }^{\text {(3) }}$ were strikingly similar to the effects which followed intravenous administration of digitalis glycosides $(9,21)$. In each instance there occurred: rapid onset of effect, fall in intracardiac pressures, decrease in vascular resistances, some decrease in heart rate, increase in cardiac output, decrease in A-V oxygen difference, slight decrease in oxygen consumption and slight decrease in arterial oxygen content and saturation. Single therapeutic doses of the glycosides generally produced more marked effects than those here evoked by primary vasodilatation, but in individual instances Arfonad ${ }^{\circledR}$ produced just as marked results as digoxin. There were, however, important differences in the results produced by the two drugs. The hemodynamic effects produced by the digitalis glycoside were sustained, whereas the responses induced by the vasodilator drug did not outlast its infusion and even tended to decrease toward the later part of the infusion. Digoxin did not lower systemic arterial pressure and usually increased it slightly. Accordingly, during the action of digoxin the lowering of intracardiac filling pressures was associated with increased cardiac minute and stroke work, in contrast to the unchanged cardiac work noted during the vasodilator action of Arfonad ${ }^{\circledR}$. The hemodynamic effects produced by digitalis glycosides were, therefore, consistent with Starling's law; the effects produced by Arfonad ${ }^{\circledR}$ were perhaps not. The differences in cardiac work produced by the two drugs permit speculation regarding a possible difference in primary action of the drugs in congested failing circulations: the glycosides affecting heart muscle directly to increase myocardial action and produce greater work, the vasodilator agent apparently having no direct myocardial effect but permitting the unaltered heart muscle to eject more blood against the lowered vascular resistance.

The renal effects of the two drugs were in striking contrast: A diuresis of water and electrolytes followed administration of digoxin, whereas Arfonad ${ }^{\circledR}$ produced a reduction in water and electrolyte excretion. This difference in urinary excretions occurred even though both drugs induced similar slight, but inconsistent, alterations in renal hemodynamic functions. In view of the reported decreased urinary excretion of water and electrolytes when renal venous pressure is raised (36-38), a reduction of elevated renal venous pressure, such as probably was produced by Arfonad $^{\circledR}$, would be expected to produce an increased renal excretion of water and electrolytes-as was the case with digoxin. The falls in systemic arterial pressure were not so great as to jeopar- 
dize glomerular filtration pressure. Furthermore, in animal experiments, diureses have been reported following removal of sympathetic innervation of the kidney (39). In view of these related findings the absence of a diuresis following Arfonad ${ }^{\circledR}$ is contrary to expectation and remains unexplained.

\section{Cardiovascular changes during vasodilatation and Starling's law}

Although the circulation, as measured by cardiac output and A-V oxygen difference, improved when the high intracardiac filling pressures in congestive heart failure were lowered, and became impaired, in the majority of instances, when the normal ventricular filling pressures of noncardiac and compensated cardiac subjects were decreased, these changes are not evidence that Starling's law was fulfilled (40). Moreover, there was a discordant observation: Often in congestive heart failure the increase in cardiac output, which occurred when the elevated filling pressures were first lowered, tended not to persist and cardiac output gradually decreased even though ventricular filling pressures remained at their lowered levels.

When Starling's law is considered in its correct terms of cardiac work, it appears that cardiac work did not increase when the elevated intracardiac filling pressures of congestive heart failure were lowered. In both normotensive and hypertensive patients with congestive heart failure, minute work index and stroke work index of both the left and right ventricles remained essentially unchanged as ventricular filling pressures fell. In the normotensive and hypertensive compensated cardiac patients and the noncardiac subjects the fall in intracardiac filling pressures was accompanied by the expected decreases in minute work index and stroke work index of both the left and right ventricles.

The interpretation of these changes in heart work in reference to Starling's law is rendered difficult, perhaps impossible, by the occurrence in the present observations of the fall in arterial pressures, both systemic and pulmonic. Since cardiac work is a function of both cardiac output and the arterial pressure against which the output is ejected, a reduction in arterial pressures repre- sents an influence toward decreased cardiac work. Thus, in the patients with congestive heart failure, the tendency for cardiac work to increase as a result of the greater cardiac output was offset by the lowering of arterial pressures and cardiac work remained essentially unchanged. In the compensated cardiac and noncardiac subjects the lowered arterial pressures had a greater influence in reducing the cardiac work than the observed small decreases in cardiac output.

Since the present experimental procedures lowered the pressures on both sides of the ventricles, it was not possible to determine the effect of changes in intracardiac filling pressures alone, as a test of Starling's law requires. However, if one accepts the work equation as a correct representation of the work performed by the heart and accordingly accepts the basic concept that work as calculated is equivalent irrespective of the differences in the individual components entering into work, then the present conditions of concomitantly lowered arterial pressures offer no bar to the application of a general principle, and hence of Starling's law. This argument would also accept as no bar the consideration that for the same calculated work, the heart tolerates (i.e., lower myocardial oxygen consumption and energy expenditure for the same amount of external work) flow work better than pressure work. Accepting these basic concepts, then the present observations suggest that Starling's law applies when ventricular filling pressures are normal but not when ventricular filling pressures are elevated. An alternative interpretation would stress the decidedly different changes in cardiac work in the two circulatory states, in relation to each other. Thus, the unchanged cardiac work during the lowering of the elevated filling pressures in congestive heart failure represents a better cardiac performance (a relative increase in work) than the decreased cardiac work associated with the fall in the normal ventricular filling pressures of the normal circulation. Such an interpretation suggests that Starling's law applies in the failing as well as in the nonfailing circulations. However, this intepretation requires that the measurements in the patients with congestive heart failure were made at the flat portion of the cardiac work-filling pressure curve, where no change in work oc- 
curs upon lowering of the filling pressure. It also requires that all 10 patients with congestive heart failure had cardiac functions of similar degrees of insufficiency-even when the degrees of congestive failure, as clinically evaluated, varied from relatively mild to very severe. Finally, this interpretation is not entirely consistent with the observed increase in cardiac output and work which occurs when patients with congestive heart failure recover compensation (22).

It is apparent that the observations in both the failing and nonfailing circulation can be interpreted as consistent with Starling's law, but in the failing circulations only if certain assumptions are made regarding the state of the congestive failure in the clinical material. It is apparent, too, that the whole issue requires observations made under conditions of unchanging arterial pressures.

\section{"Beneficial" effect of peripheral vasodilatation in congestive heart failure}

The observation that primary vasodilatation in congestive heart failure results in an increased blood flow (cardiac output) without an increase in cardiac work suggests clinical and therapeutic applications (41). Presumably lowering the pressure against which the heart must eject blood permits an impaired myocardium to circulate more blood without an intrinsic improvement in its contractile activity. Such a result can be considered of advantage to the circulation in that the supply of blood to the various organs can be increased, even when the failing myocardium is not capable of improvement and greater work. However, the present observations deal with short periods of time (one hour) and in some instances the increased cardiac output was not sustained for the entire interval of lowered vascular pressures. Accordingly, no extrapolation of the acute effects here observed to chronic vasodilatation in congestive heart failure is intended. Furthermore, should the acute decrease in urinary excretions, here produced by Arfonad ${ }^{\circledR}$, persist during chronic vasodilatation, the long term effect of this vasodilator agent could be undesirable.

\section{SUMMARY}

1) Primary peripheral vasodilatation for one hour was produced by the intravenous infusion of the ganglionic blocking agent Arfonad ${ }^{\circledR}$ in 12 cardiac subjects during congestive heart failure, in seven cardiac subjects after recovery of compensation and in two noncardiac subjects.

2) In all subjects vascular and intracardiac pressures were lowered, by 20 to 30 per cent, in both the systemic and pulmonic circulations.

3) In 8 of 10 subjects with low output congestive heart failure the lowering of vascular pressures was associated with an increase in cardiac output of approximately 15 per cent. Since the oxygen content of mixed venous blood rose and A-V oxygen difference fell, the increase in cardiac output was considered a valid one.

4) In four of five noncardiac and compensated cardiac subjects the lowering of vascular pressures resulted in a decrease in cardiac output (approximately 15 per cent), a fall in oxygen content of mixed venous blood and a small rise in $\mathrm{A}-\mathrm{V}$ oxygen difference.

5) In all groups of subjects peripheral vasodilatation was accompanied by consistent decreases in the excretion of water and sodium, while renal hemodynamic functions changed variably and slightly.

6) The effects were similar in hypertensive and normotensive subjects.

7) Because of the fall in arterial pressures against which the heart ejected blood, the increase in cardiac output during vasodilatation in the patients in congestive heart failure was achieved without increase in cardiac minute or stroke work. In the noncardiac and compensated cardiac subjects minute and stroke work of the heart decreased during vasodilatation and this decrease was due more to the fall in arterial pressure than to the decrease in cardiac output.

8) The fall in arterial pressures in the present observations makes it difficult, if not impossible, to determine whether Starling's law of the heart applies to the hemodynamic effects produced by peripheral vasodilatation. If one accepts the condition of altered arterial pressures, then Starling's law may be considered to have held in the noncardiac and compensated cardiac circulations but not in congestive heart failure, unless one assumes that cardiac function in all of these patients was on the flat portion of the cardiac workfilling pressure curve.

9) Arfonad given intravenously in congestive 
heart failure produced effects similar to digitalis glycosides with respect to decreased intracardiac pressures, increased cardiac output and decreased A-V oxygen difference. However, following digoxin, cardiac work increased and a diuresis of water and electrolytes was produced, whereas after Arfonad ${ }^{\circledR}$, cardiac work remained unaltered and water and electrolyte excretions decreased.

10) It is not clear whether the increase in blood flow without increase in cardiac work, which follows peripheral vasodilatation by Arfonad ${ }^{\circledR}$, is of benefit to the circulation in those states where the heart is so impaired that myocardial activity cannot be intrinsically improved.

\section{ACKNOWLEDGMENTS}

The authors wish to thank Mrs. Lydia Tucker, Mrs. Edna Weinick, Miss Shirilyn Shulman, Miss Eileen Maticka and Mr. Flavio Amerio for their careful technical assistance, without which these observations could not have been made.

\section{REFERENCES}

1. Frank, O. Zur Dynamik des Herzmuskels. Z. Biol. 1895, 32, 370.

2. Patterson, S. W., and Starling, E. H. On the mechanical factors which determine the output of the ventricles. J. Physiol. (Lond.) 1914, 48, 357.

3. Patterson, S. W., Piper, H., and Starling, E. H. The regulation of the heart beat. J. Physiol. (Lond.) 1914, 48, 465.

4. Starling, E. H. The Linacre Lecture on the Law of the Heart (Cambridge, 1915). London, Longmans, Green and Co., 1918.

5. Sarnoff, S. J., and Berglund, E. Ventricular function. I. Starling's law of the heart studied by means of simultaneous right and left ventricular function curves in the dog. Circulation 1954, 9, 706.

6. Isaacs, J. P., Berglund, E., and Sarnoff, S. J. Ventricular function. III. The pathologic physiology of acute cardiac tamponade studied by means of ventricular function curves. Amer. Heart J. 1954, 48, 66.

7. Sarnoff, S. J., Case, R. B., Berglund, E., and Sarnoff, L. C. Ventricular function. V. The circulatory effects of aramine; mechanism of action of "vasopressor" drugs in cardiogenic shock. Circulation 1954, 10, 84.

8. Case, R. B., Berglund, E., and Sarnoff, S. J. Ventricular function. VII. Changes in coronary resistance and ventricular function resulting from acutely induced anemia and the effect thereon of coronary stenosis. Amer. J. Med. 1955, 18, 397.

9. McMichael, J., and Sharpey-Schafer, E. P. The action of intravenous digoxin in man. Quart. J. Med. 1944, 13, 123.
10. Howarth, S., McMichael, J., and Sharpey-Schafer, E. P. Effects of venesection in low output heart failure. Clin. Sci. 1946, 6, 41.

11. Judson, W. E., Hollander, W., Hatcher, J. D., Halperin, M. H., and Friedman, I. H. The cardiohemodynamic effects of venous congestion of the legs or of phlebotomy in patients with and without congestive heart failure. J. clin. Invest. 1955, 34, 614.

12. Randall, L. O., Peterson, W. G., and Lehmann, G. The ganglionic blocking action of thiophanium derivatives. J. Pharmacol. exp. Ther. 1949, 97, 48.

13. McCubbin, J. W., and Page, I. H. Nature of the hypotensive action of a thiophanium derivative (RO 2-222) in dogs. J. Pharmacol. exp. Ther. 1952, 105, 437.

14. Cournand, A., Riley, R. L., Breed, E. S., Baldwin, E. deF., and Richards, D. W., Jr. Measurement of cardiac output in man using the technique of catheterization of the right auricle or ventricle. J. clin. Invest. 1945, 24, 106.

15. Goldring, W., and Chasis, H. Hypertension and Hypertensive Disease. New York, The Commonwealth Fund, 1944, pp. 55-63.

16. Van Slyke, D. D., and Neill, J. M. The determination of gases in blood and other solutions by vacuum extraction and manometric measurement. I. J. biol. Chem. 1924, 61, 523.

17. Behrmann, V. G., and Hartman, F. W. Rapid $\mathrm{CO}_{2}$ determination with the Beckman $\mathrm{O}_{2}$ analyzer. Proc. Soc. exp. Biol. (N. Y.) 1951, 78, 412.

18. Alving, A. S., Rubin, J., and Miller, B. F. A direct colorimetric method for the determination of inulin in blood and urine. J. biol. Chem. 1939, 127, 609.

19. Bratton, A. C., and Marshall, E. K., Jr. A new coupling component for sulfanilamide determination. J. biol. Chem. 1939, 128, 537.

20. Gibson, J. G., 2nd, and Evans, W. A., Jr. Clinical studies of the blood volume. I. Clinical application of a method employing the azo dye "Evans blue" and the spectrophotometer. J. clin. Invest. 1937, 16, 301.

21. Eichna, L. W., Farber, S. J., Berger, A. R., Earle, D. P., Rader, B., Pellegrino, E., Albert, R. E., Alexander, J. D., Taube, H., and Youngwirth, S. The interrelationships of the cardiovascular, renal and electrolyte effects of intravenous digoxin in congestive heart failure. J. clin. Invest. 1951, $30,1250$.

22. Eichna, L. W., Farber, S. J., Berger, A. R., Earle, D. P., Rader, B., Pellegrino, E., Albert, R. E., Alexander, J. D., Taube, H., and Youngwirth, S. Cardiovascular dynamics, blood volumes, renal functions and electrolyte excretions in the same patients during congestive heart failure and after recovery of cardiac compensation. Circulation 1953, 7, 674. 
23. Freis, E. D., Stanton, J. R., Culbertson, J. W., Litter, J., Halperin, M. H., Burnett, C. H., and Wilkins, R. W. The hemodynamic effects of hypotensive drugs in man. I. Veratrum viride. J. clin. Invest. $1949,28,353$.

24. Judson, W. E., Hollander, W., and Wilkins, R. W. The effects of intravenous apresoline (hydralazine) on cardiovascular and renal function in patients with and without congestive heart failure. Circulation 1956, 13, 664.

25. Freis, E. D., Rose, J. C., Partenope, E. A., Higgins, T. F., Kelley, R. T., Schnaper, H. W., and Johnson, R. L. The hemodynamic effects of hypotensive drugs in man. III. Hexamethonium. J. clin. Invest. 1953, 32, 1285.

26. Crosley, A. P., Jr., Brown, J. F., Tuchman, H., Crumpton, C. W., Huston, J. H., and Rowe, G. G. The acute hemodynamic and metabolic response of hypertensive patients to pentolinium tartrate. Circulation 1956, 14, 584 .

27. Kelley, R. T., Freis, E. D., and Higgins, T. F. The effects of hexamethonium on certain manifestations of congestive heart failure. Circulation 1953, 7, 169.

28. Shuman, C. R., Learner, N., and Doane, J. H., Jr. The effect of ganglion blocking agents in congestive heart failure. Amer. Heart J. 1954, 47, 737.

29. Burch, R. R. The effects of intravenous hexamethonium on venous pressure of normotensive and hypertensive patients with and without congestive heart failure. Circulation 1955, 11, 271.

30. Moyer, J. H., Livesay, W. R., and Seibert, R. A. The effect of blood pressure reduction with Arfonad on renal hemodynamics and the excretion of water and electrolytes. Amer. Heart J. 1954, 48, 817.

31. Ullmann, T. D., and Menczel, J. The effect of a ganglionic blocking agent (hexamethonium) on renal function and on excretion of water and electrolytes in hypertension and in congestive heart failure. Amer. Heart J. 1956, 52, 106.
32. Sarnoff, S. J., Berglund, E., and Sarnoff, L. C. Neurohemodynamics of pulmonary edema. III. Estimated changes in pulmonary blood volume accompanying systemic vasoconstriction and vasodilation. J. appl. Physiol. 1953, 5, 367.

33. Cournand, A. Some aspects of the pulmonary circulation in normal man and in chronic cardiopulmonary diseases. Circulation 1950, 2, 641.

34. Fishman, A. P., McClement, J., Himmelstein, A., and Cournand, A. Effects of acute anoxia on the circulation and respiration in patients with chronic pulmonary disease studied during the "steady state." J. clin. Invest. 1952, 31, 770.

35. Doyle, J. T., Wilson, J. S., and Warren, J. V. The pulmonary vascular responses to short-term hypoxia in human subjects. Circulation 1952, 5, 263.

36. Blake, W. D., Wegria, R., Keating, R. P., and Ward, H. P. Effect of increased renal venous pressure on renal function. Amer. J. Physiol. 1949, 157, 1.

37. Hall, P. W., III, and Selkurt, E. E. Effects of partial graded venous obstruction on electrolyte clearance by the dog's kidney. Amer. J. Physiol. 1951, 164, 143.

38. Bradley, S. E., and Bradley, G. P. The effect of increased intra-abdominal pressure on renal function in man. J. clin. Invest. 1947, 26, 1010.

39. Kaplan, S. A., and Rapoport, S. Urinary excretion of sodium and chloride after splanchnicotomy; effect on the proximal tubule. Amer. J. Physiol. 1951, 164, 175.

40. Eichna, L. W., Sobol, B. J., and Kessler, R. H. Hemodynamic and renal effects produced in congestive heart failure by the intravenous administration of a ganglionic blocking agent. Trans. Ass. Amer. Phycns 1956, 69, 207.

41. Ellestad, M. H., and Olson, W. H. Use of intravenously given ganglionic blocking agents for acute pulmonary edema, preliminary report. J. Amer. med. Ass. 1956, 161, 49. 